\title{
Genetics of Atrial Septal Defect
}

\author{
ANDRÉS SÁNCHEZ CASCOS \\ From the Cardiac and Genetic Departments, Fundación Jiménez Diaz, Madrid, Spain
}

\begin{abstract}
Sánchez Cascos, A. (1972). Archives of Disease in Childhood, 47, 581. Genetics of atrial septal defect. Of 109 cases of atrial septal defect, cases with an isolated defect ( 92 cases) showed a female preponderance (sex ratio $0 \cdot 64$ ), but there was a higher risk to the sibs of the male patients, suggesting a multifactorial mechanism.

Dermatoglyphs showed a large number of whorls on the fingers.

In 17 cases there were multiple malformations, such as Holt-Oram syndrome (hypoplastic and triphalangic thumb, with ostium secundum atrial septal defect), polydactyly plus ostium primum defect, and tracheo-oesophageal fistula.
\end{abstract}

Atrial septal defect (ASD) is one of the commoner types of congenital heart disease. Clinical diagnosis is easy and surgical correction has become a routine procedure with virtually no mortality. Even unoperated cases usually do well, so that they frequently marry and have children. These facts make ASD a suitable heart anomaly for the purposes of a genetic survey.

It is nowadays agreed that most heart anomalies are determined by a polygenic mechanism. This type of inheritance has been proved for valvular aortic stenosis (Zoethout, Bonham Carter, and Carter, 1964; Jörgensen, 1969), Fallot's tetralogy (Fuhrmann, 1968a; Sánchez Cascos, 1971), ventricular septal defect (Fuhrmann, 1968a), pulmonary stenosis (Sánchez Cascos, 1972), and transposition of the great vessels (Fuhrmann, 1968b). With regard to ASD, Nora, McNamara, and Fraser (1967), Emanuel et al. (1968), and Williamson (1969) have presented evidence in favour of a polygenic causation though some other authors (Johansson and Sievers, 1967; Bizarro et al., 1970; Zetterqvist et al., 1971) think that a monogenic dominant mechanism may be present. This was indeed an early view based on the observation of families with multiple cases of ASD in successive generations.

In this study we hoped to settle the question of polygenic versus monogenic inheritance, and also to define the genetics of ASD when this is part of a multiple malformation syndrome, whether chromosomal, monogenic, or sporadic.

\section{Material and Methods}

109 cases of ASD were studied; 84 of them belonged to the ostium secundum type (OS), and 25 to the ostium primum (OP). Cases of the so-called sinus venosus type either with or without anomalous drainage of pulmonary veins, are included in the OS variety. Cases of common atrioventricular canal (atrioventricularis communis) have been excluded.

These cases of ASD formed $15.5 \%$ of a series of 700 consecutive cases of congenital heart disease (CHD). In all cases the diagnosis was confirmed by cardiac catheterization and/or cardiac surgery. Familial data were collected from parents. All living parents, nearly half of the sibs, and all the proband's children were personally examined, clinically and by ECG and $x$-ray. Date of birth, birth rank, parental ages (at the time when the proband was born), and pathological events during pregnancy or delivery were recorded. The proband's sibs were classified as concordant (i.e. having also CHD, ASD unless otherwise stated), normal, or bearing extracardiac anomalies; the number of abortions and stillbirths was also recorded.

All cases with multiple malformations or those having extracardiac anomalies, and many others, were karyotyped.

Dermatoglyphs were taken of all 10 fingers and the right palm. We shall refer only to these parameters: (i) Finger pattern: arch (A) is the pattern with no triradius; ulnar loop (U) has one triradius in radial position; radial loop (R) has an ulnar triradius; and whorl (W) has two triradii, ulnar and radial. (ii) Total finger ridge count (TFRC) is calculated by adding the number of ridges between triradius and core for all 10 fingers. (iii) Axial palm triradius ( $t$ ). The atd angle ( $a$ and $d$ triradii are beneath forefinger and little finger) defines a proximal $t^{\circ}\left(\right.$ atd $\left.\leqslant 45^{\circ}\right)$, medial $t^{\prime}$ (atd between $46^{\circ}$ and $70^{\circ}$ ), and distal $t^{\prime \prime}\left(\right.$ atd wider than $70^{\circ}$ ). When $t$ is duplicated only the most distal is used in atd measurements).

Individuals born in Madrid during 1968 were used as controls for familial data (Madrid, Ayuntamiento, 
1968). 50 normal males and 100 normal females provided the controls for dermatoglyphs.

\section{Results}

Table I gives the numbers of cases of each type of ASD. Isolated cases and those forming part of a multiple malformation syndrome will be considered separately, as they usually have a different genetic mechanism.

\section{TABLE I}

Distribution of Ostium Secundum and Ostium Primum Defects in 92 Cases of Isolated ASD

\begin{tabular}{c|c|c|c|c}
\hline Type of ASD & Sex & Isolated & $\begin{array}{c}\text { With } \\
\text { Extracardiac } \\
\text { Malformations }\end{array}$ & Totals \\
\hline $\begin{array}{c}\text { Secundum } \\
\text { (OS-ASD) }\end{array}$ & $\begin{array}{c}\text { Male } \\
\text { Female }\end{array}$ & 28 & 6 & 34 \\
\cline { 2 - 4 } & Both sexes & 70 & 8 & 50 \\
\cline { 2 - 4 } $\begin{array}{c}\text { Primum } \\
\text { (OP-ASD) }\end{array}$ & $\begin{array}{c}\text { Male } \\
\text { Female }\end{array}$ & $\begin{array}{c}8 \\
14\end{array}$ & 14 & 84 \\
\cline { 2 - 4 } & Both sexes & 22 & 1 & 10 \\
\hline
\end{tabular}

Isolated cases. (92 cases, 70 OS-ASD, 22 흐. OP-ASD, both types with female predominance.) $\vec{\Rightarrow}$ a1. Month of birth. In neither males nor females $\stackrel{?}{\rightarrow}$ was this abnormal.

a2. Birth order (Table II). Not abnormal.

a3. Parental ages (Table III). Mean ages were $\frac{\mathscr{N}}{\overparen{D}}$ $32 \cdot 8 \pm 5 \cdot 7$ for fathers and $28 \cdot 8 \pm 5 \cdot 6$ for mothers, a normal situation.

a4. Sibs and other relatives. (Table IV). The $92 \overrightarrow{0}$ cases of ASD had 335 sibs; 11 of them (3.3\%) $\overrightarrow{\mid}$ also had CHD. These 11 belonged to 8 sibships: $\omega$ in one of them a boy with OS had a sister with aortic coarctation; in another family there were ? two cases of OP plus a third sib who had died from cyanotic CHD. In a third family, a boy with in OS had a sib who had died with a cyanotic CHD. $\perp$ The other 5 families included two sibships with 2 o cases of OP, one with 2 cases of OS and two with $\vec{\circ}$ 3 cases of OP. The percentage of recurrence was 을 higher among the sibs of male than female cases, $\vec{\longrightarrow}$ and also higher for the sibs of OP than OS cases.

All the parents were normal, though one had a right bundle-branch block. There was consanguinity of first degree in $3.2 \%$ and more distantly in $\vec{\theta}$ $4.3 \%$ of the parents. The probands had had 13 N

TABLE II

Birth Order in 92 Cases of Isolated ASD

\begin{tabular}{|c|c|c|c|c|c|c|c|}
\hline Birth Order (\%) & 1 & 2 & 3 & 4 & 5 or more & $\chi^{2}$ & $\mathbf{P}$ \\
\hline $\begin{array}{l}70 \text { OS-ASD cases } \\
\text { All sibs } \\
22 \text { OP-ASD cases } \\
\text { All sibs } \\
\text { All } 92 \text { isolated ASD cases } \\
\text { All sibs }\end{array}$ & $\begin{array}{l}27 \cdot 0 \\
21 \cdot 5 \\
27 \cdot 0 \\
22 \cdot 0 \\
27 \cdot 0 \\
21 \cdot 0\end{array}$ & $\begin{array}{l}26 \cdot 0 \\
20 \cdot 5 \\
18 \cdot 0 \\
22 \cdot 0 \\
24 \cdot 0 \\
20 \cdot 5\end{array}$ & $\begin{array}{l}14 \cdot 5 \\
17 \cdot 0 \\
32 \cdot 0 \\
19 \cdot 0 \\
18 \cdot 5 \\
17 \cdot 0\end{array}$ & $\begin{array}{r}14 \cdot 5 \\
13 \cdot 0 \\
4 \cdot 5 \\
15 \cdot 0 \\
12 \cdot 0 \\
13 \cdot 0\end{array}$ & $\begin{array}{l}18 \cdot 0 \\
28 \cdot 0 \\
18 \cdot 5 \\
22 \cdot 0 \\
18 \cdot 5 \\
28 \cdot 5\end{array}$ & $5 \cdot 9$ & $<0.3$ \\
\hline
\end{tabular}

TABLE III

Parental Ages in 92 Cases of Isolated ASD

\begin{tabular}{|c|c|c|c|c|c|c|c|c|c|}
\hline \multirow[b]{3}{*}{$\begin{array}{l}\text { Fathers } \\
70 \text { OS-ASD cases } \% \\
22 \text { OP-ASD cases } \%\end{array}$} & \multicolumn{9}{|c|}{ Years } \\
\hline & -20 & $21-25$ & $26-30$ & $31-35$ & $36-40$ & $41-45$ & $46-$ & $x^{2}$ & $\mathbf{P}$ \\
\hline & $\begin{array}{l}0 \\
0\end{array}$ & $\begin{array}{l}7 \\
0\end{array}$ & $\begin{array}{l}30 \\
33\end{array}$ & $\begin{array}{l}32 \\
48\end{array}$ & $\begin{array}{l}16 \\
14\end{array}$ & $\begin{array}{l}9 \\
5\end{array}$ & $\begin{array}{l}6 \\
0\end{array}$ & & \\
\hline $\begin{array}{l}\text { Mothers } \\
70 \text { OS-ASD cases \% } \\
22 \text { OP-ASD cases \% }\end{array}$ & $\begin{array}{l}2 \\
5\end{array}$ & $\begin{array}{l}28 \\
28\end{array}$ & $\begin{array}{l}28 \\
33\end{array}$ & $\begin{array}{l}25 \\
24\end{array}$ & $\begin{array}{r}15 \\
5\end{array}$ & $\begin{array}{l}2 \\
5\end{array}$ & & & \\
\hline $\begin{array}{l}\text { Total ASD \% } \\
\text { Normal controls }\end{array}$ & $\begin{array}{l}2 \\
2\end{array}$ & $\begin{array}{l}29 \\
22\end{array}$ & $\begin{array}{l}30 \\
32\end{array}$ & $\begin{array}{l}25 \\
27\end{array}$ & $\begin{array}{l}12 \\
11\end{array}$ & $\begin{array}{l}2 \\
3\end{array}$ & & $2 \cdot 2$ & $<0.8$ \\
\hline
\end{tabular}


TABLE IV

Pedigree in 92 Cases of Isolated ASD

\begin{tabular}{|c|c|c|c|c|c|c|c|c|}
\hline & \multicolumn{2}{|c|}{ Consanguinity } & \multicolumn{6}{|c|}{ Sibs } \\
\hline & First Degree & Other & With & D \% & Without CHD & Abortions & Stillbirths & Total \\
\hline $\begin{array}{l}\text { Males } \\
28 \text { OS-ASD cases } \\
8 \text { OP-ASD cases }\end{array}$ & $\begin{array}{l}1 \\
1\end{array}$ & $\begin{array}{l}2 \\
1\end{array}$ & $\begin{array}{l}3 \\
4\end{array}$ & $\begin{array}{r}3 \\
13\end{array}$ & $\begin{array}{l}95 \\
24\end{array}$ & $\begin{array}{l}6 \\
3\end{array}$ & $\begin{array}{l}4 \\
1\end{array}$ & $\begin{array}{r}108 \\
32\end{array}$ \\
\hline Total 36 ASD cases & 2 & 3 & 7 & 5 & 119 & 9 & 5 & 140 \\
\hline $\begin{array}{l}\text { Females } \\
42 \text { OS-ASD cases } \\
14 \text { OP-ASD cases }\end{array}$ & $\begin{array}{l}0 \\
1\end{array}$ & $\begin{array}{l}1 \\
0\end{array}$ & $\begin{array}{l}0 \\
4\end{array}$ & $\begin{array}{l}0 \\
9\end{array}$ & $\begin{array}{r}127 \\
36\end{array}$ & $\begin{array}{r}16 \\
6\end{array}$ & $\begin{array}{l}5 \\
1\end{array}$ & $\begin{array}{r}148 \\
47\end{array}$ \\
\hline Total 56 ASD cases & 1 & 1 & 4 & 3 & 163 & 22 & 6 & 195 \\
\hline
\end{tabular}

$\mathrm{CHD}=$ congenital heart disease.

TABLE V

Dermatoglyphs (\% distribution) in 92 Cases of Isolated ASD

\begin{tabular}{|c|c|c|c|c|c|c|c|c|c|c|c|}
\hline & $\mathbf{U}$ & W & $\mathbf{R}$ & $\mathbf{A}$ & $\chi^{2}$ & $\mathbf{P}$ & $t^{\circ}$ & $t^{\prime}$ & $t^{\prime \prime}$ & $x^{2}$ & $\mathbf{P}$ \\
\hline $\begin{array}{l}\text { Males } \\
\text { OS-ASD cases } \\
\text { OP-ASD cases }\end{array}$ & $\begin{array}{l}52 \\
66\end{array}$ & $\begin{array}{l}37 \\
20\end{array}$ & $\begin{array}{l}4 \\
9\end{array}$ & $\begin{array}{l}7 \\
5\end{array}$ & & & $\begin{array}{l}80 \\
87\end{array}$ & $\begin{array}{l}20 \\
13\end{array}$ & $\begin{array}{l}0 \\
0\end{array}$ & & \\
\hline $\begin{array}{l}\text { Total ASD cases } \\
\text { Controls }\end{array}$ & $\begin{array}{l}55 \\
67\end{array}$ & $\begin{array}{l}34 \\
22\end{array}$ & $\begin{array}{l}5 \\
5\end{array}$ & $\begin{array}{l}6 \\
6\end{array}$ & $29 \cdot 7$ & $<0.001$ & $\begin{array}{l}82 \\
86\end{array}$ & $\begin{array}{l}18 \\
14\end{array}$ & $\begin{array}{l}0 \\
0\end{array}$ & $1 \cdot 1$ & $<0.3$ \\
\hline $\begin{array}{l}\text { Total ASD cases } \\
\text { Controls }\end{array}$ & $\begin{array}{l}61 \\
68\end{array}$ & $\begin{array}{l}32 \\
22\end{array}$ & $\begin{array}{l}2 \\
5\end{array}$ & $\begin{array}{l}6 \\
5\end{array}$ & $39 \cdot 5$ & $<0.001$ & $\begin{array}{l}73 \\
83\end{array}$ & $\begin{array}{l}21 \\
16\end{array}$ & $\begin{array}{l}6 \\
1\end{array}$ & $5 \cdot 9$ & $<0.1$ \\
\hline
\end{tabular}

For dermatoglyphic notation, see text.

children, all normal. Two uncles and one cousin of the probands also had ASD.

a5. Pregnancy and delivery. Nothing relevant was found.

a6. Finger pattern (Table V). Both sexes had a reduced number of ulnar loops $(55 \%$ and $61 \%$ versus $67 \%$ and $68 \%$ in controls) and a proportional increase in whorls $(33.5 \%$ and $32.3 \%$ versus $22 \%$ in controls). These differences were significant for both sexes.

a7. TFRC. This measured $127 \pm 50$ in OS males and $126 \cdot 5 \pm 41$ in females. These values did not differ from controls (normal males had TFRC $=150 \pm 54 ; \mathrm{SD}=12 \cdot 14, t=1 \cdot 8$; normal females had TFRC $=127 \pm 40 ; \mathrm{SD}=8 \cdot 1, t=$ $0 \cdot 06$ ).

a8. Palm axial triradius (Table V). The proportions of $t^{\circ}, t^{\prime}$, and $t^{\prime \prime}$ positions did not differ from controls.

a9. Karyotype. All analysed cases had normal chromosomes.
Multiple malformation syndromes with OS-ASD. There were 14 cases in this category, 6 male, 8 female.

b1. Down's syndrome (mongolism). One boy, also having persistent ductus arteriosus had trisomy21 , and showed the typical high maternal age and $t^{\prime \prime}$ position of the axial triradius.

b2. Edwards' syndrome. One boy with trisomy18; he had young parents; his dermatoglyphs were not recorded.

b3. $X X X$ syndrome. A girl with $47, \mathrm{XXX}$ had middle-aged parents (56 and 36 years). Dermatoglyphs were unremarkable.

b4. Turner's syndrome. A girl with typical features and chromosomes XO, had $9 \mathrm{~W}$ on her fingers.

b5. Turner's phenotype in a female with normal karyotype $(46, X X)$ (Bonnevie-Ulrich or Noonan's syndrome). This girl also had pulmonary valve stenosis and aortic coarctation. She had hypertelorism, webbing of the neck, kyphoscoliosis, 

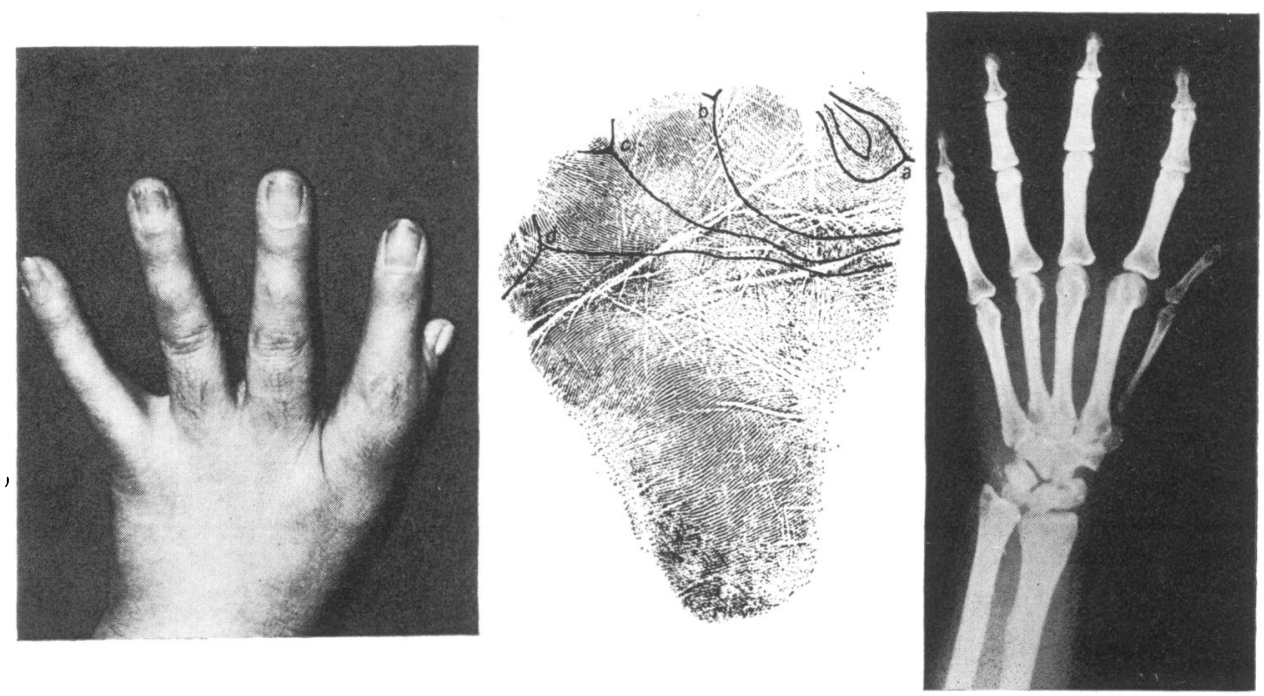

Fig. 1.-Holt-Oram syndrome. See the hypoplastic, triphalangic, syndactylic thumb, and the absence of the $\mathrm{t}$ triradius $\gg$ on the palm (partly reproduced from Sánchez Cascos, A.-(1967), Acta Paediatrica Scandinavica, 56, 313, Fig. 2, ్ㅡ with permission of the Editor).

and other somatic anomalies. Her dermatoglyphs showed $9 \mathrm{~W}$ on the fingers, a high TFRC (162), and a $t^{\prime}$ position of the axial triradius. Her ECG was atypical and has been published elsewhere (Sánchez Cascos, 1972).

b6. Holt-Oram syndrome. 4 cases (2 of each sex) belonged to the atrio-digital dysplasia syndrome of
Holt-Oram. One was a sporadic case, the other $\vec{\varphi}$ three formed a sibship that has been reported N previously (Sánchez Cascos, 1967). Fig. 1 and 2 잉 show the typical hypoplastic, syndactylic, distally placed, and sometimes triphalangic thumb; also the distal placement or even absence of the axial palm triradius $(t)$. Sinus arrhythmia with $\mathrm{AV} \stackrel{\circ}{\mathbb{D}}$
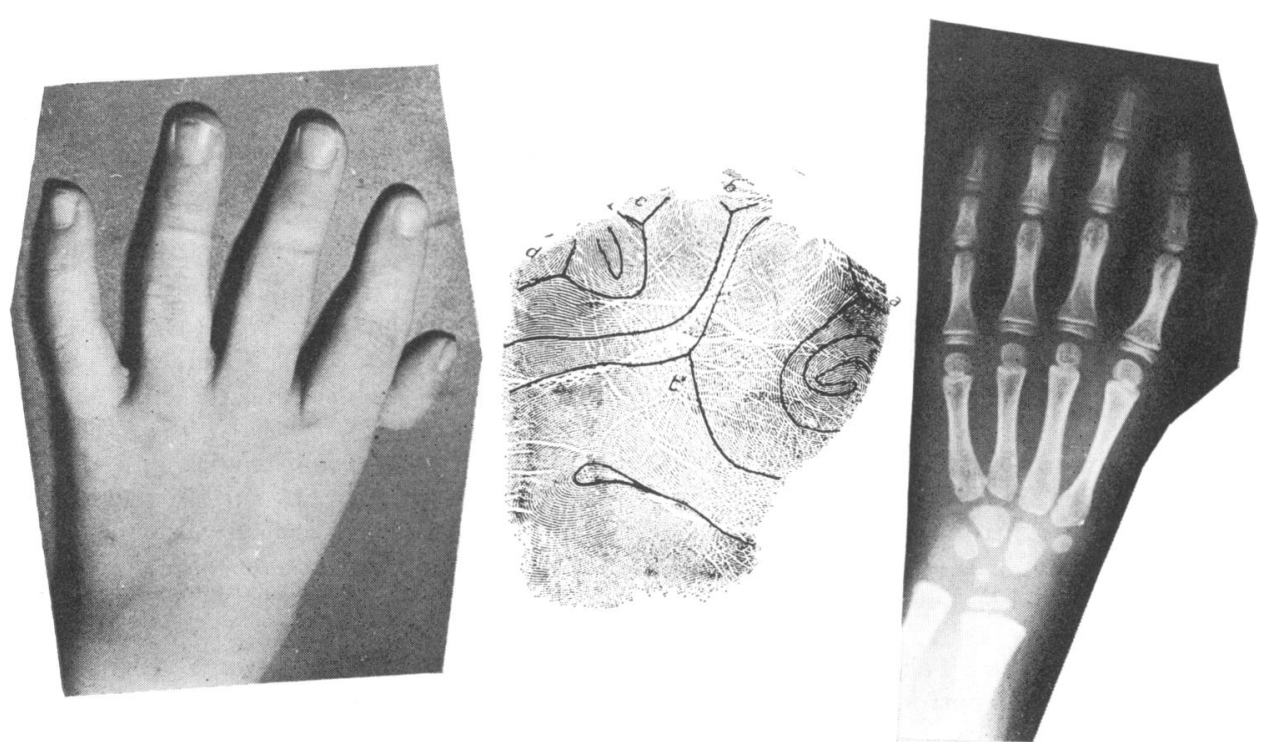



FIG. 2.-Holt-Oram syndrome. Absence of the metacarpal, hypoplastic thumb, distal $\mathrm{t}^{\prime \prime}$ axial triradius, and thenar pattern. 
junctional escapes is characteristic, and was present in two cases.

b7. Cleido-cranial dysplasia. One girl showed absence of both clavicles, cervical hemivertebrae, visceral situs inversus, and the skull deformities typical of the cleido-cranial dyplasia. She had a low TFRC (50) and high $t^{\prime}$ axial triradius.

b8. Deaf mutism. This was present in two cases, one of each sex. The boy had a sib, also a deafmute, and a high $t^{\prime}$ triradius.

b9. Tracheo-oesophageal fistula. This was present in one girl, who also had ventricular septal defect and persistent ductus arteriosus.

b10. Cerebral sclerosis plus optic atrophy. This was present in one boy; 2 of his 4 sibs had died with a similar neurological condition, but their heart condition was unknown.

Multiple malformation syndromes with OP-ASD. There were 3 cases, 2 male, 1 female. c1. Polydactyly. Two cases, one of each sex, presented with polydactyly. The boy also had ungual dysplasia (Fig. 3). The girl had a $t^{\prime \prime}$

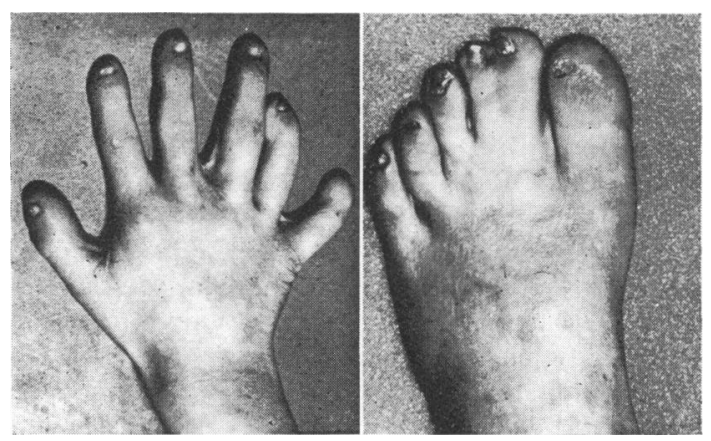

Fig. 3.-Polydactyly and nail dysplasia in a boy with ostium primum.

distal triradius; in her pedigree were 4 polydactylic members in 2 generations, but their heart condition is unknown.

c2. Cleft lip, tracheo-oesophageal fistula, hypertelorism, and hypospadias. This boy presented 7 arches on his fingers and consequently his TFRC was very low (18); the axial triradius was in $t^{\prime}$ position. This patient seems to be an example of the so-called BBB syndrome (see below).

\section{Discussion}

Several previous papers contain impressive records of families with multiple cases of ASD, in one or successive generations (Carleton, Abel- mann, and Hancock, 1958; Weinstein, 1958; Campbell, 1959; Weil and Allenstein, 1959; Allenstein and Weil, 1960). Campbell and Polani (1961) reported one of these families, with 5 proved plus 4 suspected cases in 5 generations, and collected from the literature 51 families with multiple cases of ASD.

Kahler et al. (1966), Ehlers and Engle (1966), Nora et al. (1967), Amarasingham and Fleming (1967) have also published families with multiple cases of ASD, and recently Zetterqvist et al. (1971) reported a family with a least 16 cases. Bizarro et al. (1970) have emphasized the common occurrence of a long PR interval in familial cases of ASD, a feature already noted in the reports of Kahler and Amarasingham, and suggested that a long $P R$ interval is indicative of a dominant inheritance in ASD.

We have reviewed the PR interval in our familial cases of ASD. Only one case had a long PR, but it was an OP case and in OP defects this feature is not uncommon. Nevertheless, the possibility remains that cases of 'OS-ASD with long PR' belong to a monogenic syndrome, in relation to the Holt-Oram syndrome (see below).

Familial aggregation occurs in polygenic inheritance (Edwards, 1960; Nora, 1968; Carter, 1969). In this situation the incidence of the anomaly in first degree relatives (parents, sibs, and offspring) is $\sqrt{ } p$, where $p$ is the incidence of the trait in the normal population. In our series there were 109 cases of ASD in 700 consecutive cases of CHD (15.5\%). Accepting a general incidence for all types of $\mathrm{CHD}$ of about 0.005 live newborns (McKeown, McMahon, and Parsons, 1953; Carlgren, 1959) the natural occurrence of ASD should be $0.005 \times 0.155 \approx 0.0008$. If a multifactorial mechanism is the underlying cause, the risk of reccurrence in sibs (and also in offspring) would be as high as $\sqrt{ } 0.0008 \approx 3 \%$.

Nora et al. (1967) reported $3.7 \%$ affected sibs and $3.5 \%$ affected parents in a series of 100 cases of ASD. Williamson (1969) found 3.7\% affected sibs and $3.8 \%$ affected children in another series of 135 cases of ASD. Emanuel et al. (1968) in 92 cases of OP-ASD found $1 \cdot 1 \%$ affected parents, $1 \cdot 7 \%$ affected sibs, and $10 \%$ affected children. In two older series (Lamy, de Grouchy, and Schweisguth, 1957; Campbell and Polani, 1961) the incidence in sibs was $1 \cdot 24 \%$ and $1 \cdot 1 \%$; in the latter study $1.3 \%$ of the parents were also concordant. All these figures agree with theoretical expectations. Our results were similar, with $3.3 \%$ concordant sibs.

In multifactorial inheritance patients of the less 
affected sex are found to be associated with the greater incidence among their relatives. This was so in our series, where the incidence of ASD in the sibs of male patients was $5 \%$, while that for female patients was only $2.5 \%$. The higher risk for the more severe type $(12.5 \%$ for the sibs of OP males) also is in keeping with this pattern of inheritance, as is the high rate of parental consanguinity, $3.2 \%$ of first degree, compared with less than $2 \%$ in the Spanish population (Valls, 1967). Another feature of polygenic inheritance is a sex ratio which deviates from 1 , and this series gave 0.64 males to 1 female.

We have found that both Fallot's tetralogy (Sánchez Cascos, 1971) and pulmonary stenosis (Sánchez Cascos, 1972) present dermatoglyphic features that deviate from the normal. In the present series of ASD we found a high proportion of whorls, and a parallel diminution in the numbers of ulnar loops. The other dermatoglyphic findings were not significant (position of $t$ axial triradius and TFRC).

With regard to the specific types of heart lesion found in multiple malformation syndromes, we shall only refer to those syndromes represented in the present series.

(i) Chromosome imbalance syndromes. Both 21-trisomy (Down's syndrome) and 18-trisomy (Edwards' syndrome) are often associated with CHD. Though the commonest heart lesions are atrioventricularis communis in the former and ventricular septal defect in the latter, ASD is by no means uncommon (Taylor, 1968; Cullum and Liebman, 1969).

In the $\mathrm{X}$ chromosome imbalance syndromes heart involvement is not so frequent. Aortic coarctation is the typical anomaly in $\mathrm{X}$ monosomy (Turner's syndrome), but ASD is also found (Bishop, Lessof, and Polani, 1960; Emerit et al., 1967). On the other hand, the XXX syndrome rarely coexists with CHD, though ASD seems to be the commonest anomaly (Barr et al., 1969). The lesions in the Noonan or Bonnevie-Ulrich syndrome, where the karyotype is normal, often include CHD; pulmonary stenosis is the most frequent anomaly, but ASD is also found (ChavesCarballo and Hayles, 1966; Emerit et al. 1967; Noonan, 1968).

(ii) Holt-Oram and related syndromes. It is now well known that a number of conditions can produce $\mathrm{CHD}$ plus regression of the first ray of the hand. Apart from the Dr syndrome (ring chromosome in the group 13-15), Fanconi's anaemia, and other rarer conditions, there are two major syndromes, the Holt-Oram and Lewis syndromes, both autosomal dominant, with this phenotypic expression.

The Holt-Oram syndrome (Holt and Oram, 1960; McKusick, 1961; Zetterqvist, 1963; Sánchez Cascos, 1967; Antia, 1970, etc.) comprises OS-ASD, AV junctional escapes, or AV block, and a hypoplastic syndactylic, and triphalangic thumb, with hypoplasia of the first metacarpal and external carpal bones. The term atriodigital dysplasia, coined by McKusick (1961), seems to be appropriate.

The Lewis syndrome (Kuhn, Schaaf, and Wagner, 1963; Lewis, Bruce, and Motulsky, 1964; Holmes, 1965; Gall et al., 1966; Simcha, 1971; Sánchez Cascos, 1971) comprises a more severe type of CHD-ventricular septal defect, Fallot's tetralogy or transposition of the great arteries-hypoplasia of the radius with subsequent aplasia of the first carpometacarpal ray, and sometimes aberrant ECG (Sánchez Cascos, 1971). McKusick's term ventriculo-radial dysplasia seems appropriate.

We believe the two syndromes to be different, though their phenotypes may overlap. The typical palm dermatoglyphs, shown in Fig. 1 and 2, are related to the absence or hypoplasia of the thumb.

Another syndrome with involvement of the heart and the hand is represented by our two cases of OP-ASD with polydactyly and nail dystrophy. A case of OP-ASD plus polydactyly has been published by Cleland et al. (1969). Fuhrmann (1968a) has reported two cases of CHD with polydactyly, one with ventricular septal defect, the other with truncus arteriosus. Other cases of polydactyly presented septal defects (Tünte, 1968), aortic coarctation (Veno, Bansho, and Kawashima, 1968), and truncus arteriosus (Van Praagh and Van Praagh, 1965). This syndrome seems to be related to the well-known autosomal recessive syndrome of Ellis-van Creveld, in which polydactyly, dwarfism, dysplastic nails, and abnormal teeth co-exist with $\mathrm{CDH}$ - usually common atrium, but also ventricular septal defect or atrioventricularis communis (Tubbs, Crevasse, and Green, 1962; Giknis, 1963; McKusick, 1964; Behar and Rachmilewitz, 1964; Goor et al., 1965; Lynch et al., 1968).

(iii) Other syndromes with ASD. Many other syndromes have been reported in which ASD is present. In tracheo-oesophageal fistula (with or without oesophageal atresia) ASD was present in 20 of 183 cases (Mellins and Blumenthal, 1964) and in 9 of 87 cases (Daum, Hecker, and Rüter, 1969), but was not represented in a series 
of 39 necropsied cases (Mehrizi, Folger, and Rowe, 1966).

Opitz, Summitt, and Smith (1969) have coined the term $B B B$ syndrome for the association of hypertelorism, hypospadias, and CHD-OP-ASD in one of their two cases. One case in our series would conform to this description.

Finally we have two cases of deaf-mutism plus OS-ASD previously reported in detail (Sánchez Cascos, Sánchez-Harguindey, and de Rábago, 1969).

In many of these syndromes, the type of heart lesion is not specific, while in others it is, such as OS-ASD in Holt-Oram syndrome and perhaps OP-ASD in polydactyly.

\section{REFERENCES}

Allenstein, B. J., and Weil, M. H. (1960). Congenital heart disease in five members of one family. (Abst.) Circulation, 22, 716.

Amarasingham, R., and Fleming, H. A. (1967). Congenital heart disease with arrhythmia in a family. British Heart fournal, 29, 78.

Antia, A. U. (1970). Familial skeletal cardiovascular syndrome (Holt-Oram) in a polygamous African family. British Heart fournal, 32, 241.

Barr, M. L., Sergovich, F. R., Carr, D. H., and Shaver, E. L. (1969). The triplo-X female: an appraisal based on a study of 12 cases and a review of the literature. Canadian Medical Association fournal, 101, 247.

Behar, A., and Rachmilewitz, E. (1964). Ellis-van Creveld syndrome: report of one case associated with abiotrophy of elastic tissue in the cardiovascular system. Archives of Internal Medicine, 113, 606.

Bishop, P. M. F., Lessof, M. H., and Polani, P. E. (1960). Turner's syndrome and allied conditions. Memoirs of the Society of Endocrinology, 7, 162.

Bizarro, R. O., Callahan, J. A., Feldt, R. H., Kurland, L. T., Gordon, H., and Brandenburg, R. O. (1970). Familal atrial septal defect with prolonged atrioventricular conduction. Circulation, 41, 677.

Campbell, M. (1959). The genetics of congenital heart disease and situs inversus in sibs. British Heart fournal, 21, 65.

Campbell, M., and Polani, P. E. (1961). Factors in the aetiology of atrial septal defect. British Heart fournal, 23, 477.

Carleton, R. A., Abelmann, W. H., and Hancock, E. W. (1958). Familial occurrence of congenital heart disease. Report of three families and review of the literature. New England fournal of Medicine, 259, 1237.

Carlgren, L. (1959). The incidence of congenital heart disease in children born in Gothenburg 1941-50. British Heart Fournal, $21,40$.

Carter, C. O. (1969). Genetics of common disorders. British Medical Bulletin, 25, 52.

Chaves-Carballo, E., and Hayles, A. B. (1966). Ulrich-Turner syndrome in the male: review of the literature and report of a case with lymphocytic (Hashimoto's) thyroiditis. Mayo Clinic Proceedings, 41, 843.

Cleland, W., Goodwin, J., McDonald, L., and Ross, D. (1969). Medical and Surgical Cardiology. Blackwell, Oxford.

Cullum, L., and Liebman, J. (1969). The association of congenital heart disease with Down's syndrome (mongolism). American Fournal of Cardiology, 24, 354.

Daum, R., Hecker, W. C., and Rüter, E. (1969). Analyse von 87 Oesophagusatresien. Langenbecks Archiv für klinische Chirurgie, 323, 292.

Edwards, J. H. (1960). Simulation of Mendelism. Acta Genetica et Statistica Medica, 10, 63.

Ehlers, K. H., and Engle, M. A. (1966). Familial congenital heart disease. I. Genetic and environmental factors. Circulation, 34, 503.

Emanuel, R., Nichols, J., Anders, J. M., Moores, E. C., and Somerville, J. (1968). Atrioventricular defects: a study of 92 families. British Heart fournal, 30, 645.
Emerit, I., Vernant, P., Corone, P., and de Grouchy, J. (1967). Malformations extracardiaques associées à des cardiopathies congénitales (Étude statistique portant sur 1000 cas). Acta Geneticae Medicae et Gemellologiae, 16, 27.

Fuhrmann, W. (1968a). Congenital heart disease in sibships ascertained by two affected siblings. Humangenetik, 6, 1.

Fuhrmann, W. (1968b). A family study in transposition of the great vessels and in tricuspid atresia. Humangenetik, 6, 148.

Gall, J. C., Jr., Stern, A. M., Cohen, M. M., Adams, M. S., and Davidson, R. T. (1966). Holt-Oram syndrome: clinical and genetic study of a large family. American fournal of Human Genetics, 18, 187.

Giknis, F. L. (1963). Single atrium and the Ellis-van Creveld syndrome. Fournal of Pediatrics, 62, 558.

Goor, D., Rotem, Y., Friedman, A., and Neufeld, H. N. (1965). Ellis-van Creveld syndrome in identical twins. British Heart fournal, 27, 797.

Holmes, L. B. (1965). Congenital heart disease and upperextremity deformities. A report of two families. New England Fournal of Medicine, 272, 437.

Holt, M., and Oram, S. (1960). Familial heart disease with skeletal malformations. British Heart fournal, 22, 236.

Johansson, B. W., and Sievers, J. (1967). Inheritance of atrial septal defect. Lancet, 1, 1224.

Jörgensen, G. (1969). Genetische Untersuchungen bei angeborener organischer subvalvulärer Aortenstenose. Humangenetik, 7, 51.

Kahler, R. L., Braunwald, E., Plauth, W. H., Jr., and Morrow, A. G. (1966). Familial congenital heart disease. Familial occurrence of atrial septal defect with A-V conduction abnormalities; supravalvular aortic and pulmonic stenosis; and ventricular septal defect. American fournal of Medicine, 40,

384.
Kuhn, E., Schaaf, J., and Wagner, A. (1963). Primary pulmonary hypertension, congenital heart disease and skeletal anomalies in three generations. Fapanese Heart fournal, 4, 205.

Lamy, M., de Grouchy, J., and Schweisguth, O. (1957). Genetic and non-genetic factors in the etiology of congenital heart disease: a study of 1188 cases. American fournal of Human Genetics, 9, 17.

Lewis, K. B., Bruce, R. S., and Motulsky, A. G. (1964). Upper limb cardiovascular syndrome: an autosomal dominant genetic effect on embryogenesis. (Abst.) Circulation, 29-30, Suppl. 3,113 .

Lynch, J. I., Perry, L. W., Takakuwa, T., and Scott, L. P. (1968). Congenital heart disease and chondroectodermal dysplasia. Report of two cases, one in a Negro. American fournal of Diseases of Children, 115, 80.

Mckeown, T., McMahon, B., and Parsons, C. G. (1953). The familial incidence of congenital malformation of the heart. British Heart Fournal, 15, 273.

McKusick, V. A. (1961). Medical Genetics, 1958-60. An Annotated Review, p. 426. Mosby, St. Louis.

McKusick, V. A. (1964). A genetical view of cardiovascular disease. Circulation, 30, 326.

Madrid, Ayuntamiento (1968). Resumen estadistico 1968. Secretaría General del Ayuntamiento, Madrid.

Mehrizi, A., Folger, G. M., Jr., and Rowe, R. D. (1966). Tracheoesophageal fistula associated with congenitial cardiovascular malformations. Bulletin of the fohns Hopkins Hospital, 118, 246.

Mellins, R. B., and Blumenthal, S. (1964). Cardiovascular anomalies and esophageal atresia. American fournal of Diseases of Children, 107, 160.

Noonan, J. A. (1968). Hypertelorism with Turner phenotype. A new syndrome with associated congenital heart disease. American Fournal of Diseases of Children, 116, 373.

Nora, J. J. (1968). Multifactorial inheritance hypothesis for the etiology of congenital heart disease: the genetic-environmental interaction. Circulation, 38, 604.

Nora, J. J., McNamara, D. G., and Fraser, F. C. (1967). Hereditary factors in atrial septal defect. Circulation, 35, 448.

Opitz, J. M., Summitt, R. L., and Smith, D. W. (1969). The BBB syndrome: familial telecanthus with associated congenital anomalies. In The First Conference on the Clinical Delineation of Birth Defects Part II: Malformation syndromes (Birth Defects : Original Article Series, Vol. 5, no. 2, p. 86. Ed. by D. Bergsma. National Foundation March of Dimes, New York. 
Sánchez Cascos, A. (1967). Holt-Oram syndrome. Acta Paediatrica Scandinavica, 56, 313.

Sánchez Cascos, A. (1971). Genetics of Fallot's tetralogy. British Heart fournal, 33, 899 .

Sánchez Cascos, A. (1972). Genetics of pulmonic stenosis. Acta Cardiologica. (In the press.)

Sánchez Cascos, A., Sánchez-Harguindey, L., and de Rábago, P. (1969). Cardio-auditory syndromes: cardiac and genetic study of 511 deaf-mute children. British Heart fournal, 31, 26.

Simcha, A. (1971). Congenital heart disease in radial clubbed hand syndrome. Archives of Disease in Childhood, 46, 345.

Taylor, A. I. (1968). Autosomal trisomy syndromes: a detailed study of 27 cases of Edwards' syndrome and 27 cases of Patua's syndrome. Fournal of Medical Genetics, 5, 227.

Tubbs, F. E., Crevasse, L., and Green, J. R., Jr. (1962). Congenital heart disease in an adult with the Ellis-van Creveld syndrome. Annals of Internal Medicine, 57, 829.

Tünte, W. (1968). A new polydactyly/imperforate-anus/vertebralanomalies syndrome? (Letter.) Lancet, $2,1081$.

Valls, A. (1967). Consanguineous marriages in a Spanish population. Acta Genetica et Statistica Medica, 17, 112.

Van Praagh, R., and Van Praagh, S. (1965). The anatomy of common aorticopulmonary trunk (truncus arteriosus communis) and its embryologic implications: a study of 57 necropsy cases. American fournal of Cardiology, 16, 406.
Veno, M., Bansho, N., and Kawashima, N. (1968). A case of polydactylism of a newborn infant. Proceedings of the Congenital Anomalies Research Association of fapan, 8, 25.

Weil, M. H., and Allenstein, B. J. (1959). Familial occurrence of defects of the interatrial septum. (Abst.) Circulation, 20, 782.

Weinstein, A. (1958). Congenital heart disease in successive generations: interatrial septal defect in a 63-year-old woman and her 31-year-old son. Fournal of Chronic Diseases, 8, 669. Williamson, E. M. (1969). A family study of atrial septal defect. Fournal of Medical Genetics, 6, 255.

Zetterqvist, P. (1963). The syndrome of familial atrial septal defect, heart arrhythmia and hand malformation (Holt-Oram) in mother and son. Acta Paediatrica, 52, 115.

Zetterqvist, P., Turesson, I., Johansson, B. W., Laurell, S., and Ohlsson, N. (1971). Dominant mode of inheritance in atrial septal defect. Clinical Genetics, 2, 78.

Zoethout, H. E., Bonham Carter, R. E., and Carter, C. O. (1964) A family study of aortic stenosis. Fournal of Medical Genetics, $1,2$.

Correspondence to Dr. A. Sánchez Cascos, Dpts. Cardiologia y Genetica, Clinica de la Concepción, Reyes Catolicos 2, Madrid, Spain. 